\title{
Mineralogical-Geochemical Criteria for Geometallurgical Mapping of Levoberezhnoye Au Deposit (Khabarovsk Region, Russia)
}

\author{
I. Anisimov ${ }^{(\bowtie)}$, A. Sagitova, M. Kharitonova, A. Dolotova, \\ and I. Agapov \\ Polymetal Engineering JSC, Saint-Petersburg, Russia \\ anisimovis@polymetal.ru
}

\begin{abstract}
Levoberezhnoye gold deposit is located in Khabarovsk region. It formed quartz-sulfide and quartz-adularia veining and fracture zones in argillic altered intermediate volcanic tuffs and lavas. 61 variability study samples were composed of quartz, feldspar, mica, kaolinite, chlorite with minor pyrite, arsenopyrite, jarosite and accessories. Multivariate statistics of mineral composition and multi-element assays distinguished following ore types: (1) primary quartz-feldspar sulfide-bearing breccia veins, (2) oxidized breccias with micas transformed to illite-smectite; (3) high sulfidation quartz-kaolinite. Gold leach recovery correlated with high sulfate content as well as mica and chlorite transformation to illite and smectite. Low sulfidation ores showed lower leaching recovery connected to gold encapsulation in pyrite. Thus, oxidized and sulfate ore types were amenable to cyanidation, while primary ore was recommended for sulfide flotation gold recovery. Molybdenum high content connected to $\mathrm{Ag}, \mathrm{Cu}, \mathrm{Pb}$ and $\mathrm{As}$ and supposed to be formed in a separate mineralization event from gold.
\end{abstract}

Keywords: Gold recovery $\cdot$ Cyanidation $\cdot$ Oxidation $\cdot$ Illite-smectite

\section{Introduction}

Levoberezhnoye deposit is located in Khabarovsky region in Estern Russia. It is localized in intermediate volcanics and formed steeply dipping quartz-adularia $\mathrm{Au}-\mathrm{Ag}$ breccia-vein system imbedded in rhyolites and extensively altered lake and flow tuffs and ignimbrite volcanics. The ore bearing rocks suffered multiple hydrothermal brecciation events with quartz \pm adularia-sulfide cement and fine sulfide dissemination in altered volcanics. The veining and rocks are fine grained and hard for visual mineral identification.

The samples characterized with drastic variations in gold recovery by cyanidation from 19 to $99 \%$. The aim of the work was to determine compositional differences in ore types and ore characteristics effected gold recovery and cased metal losses. 


\section{Methods and Approaches}

61 composite drill core sample of geotechnical mapping of Levoberezhnoe were studied for cyanadation leaching and bulk mineral composition. Sample color was described with RGB-parameters.

$\mathrm{Au}$ was assayed with fire assay with atomic absorption finish, multi-element ICPAES assays after four acid digestion of straight and diluted samples and XRF-analysis, sulfide and total $\mathrm{S}$, total $\mathrm{C}$ estimated by LECO analysis.

Mineral phase identification and their quantification was done using Eva software and COD database. Quantitative X-ray powder diffraction with Rietveld refinement Topas software at Polymetal Engineering.

Multivariate statistical analysis was performed on filtered data with Aitchison transformation using Pearson correlations with Cytoscape software, PCA and regression analyses.

\section{Results and Discussion}

Three main ore types were distinguished based on mineral composition: 1 - quartzalbite with sulfide (arsenopyrite-pyrite) mineralization, 2 - kaolinite-dickite with sulfate, 3 - illite-smectite.

Wide structural and chemical variety of feldspars was observed: high and low microcline, orthoclase, albite and hyalophane. Balancing mineral content QXRD results for micas and $\mathrm{K}$-felpdspars revealed significant potassium shortage and suggested high baddingtonite content in feldspar, which needs confirmation with assays. Observed anomalously high values of molybdenum were connected to $\mathrm{Ag}, \mathrm{Pb}, \mathrm{Au}$ and $\mathrm{Cu}$.

Multivariate statistics analyses included 73 following parameters: chemical and mineral composition, color (RGB, brightness - BRT and darkness - DRN), material fineness $(\gamma+100)$, Au recovery $-\varepsilon A u$ and losses $--\varepsilon$ Au. Pearson positive correlations revealed occurrence of 5 geochemical and mineral clusters (Fig. 1):

1 - quartz-kaolinite-albite-sulfate with zeolites, $\mathrm{Sr}$ enriched (high sulfidation alteration); 2 - micas-chlorite with calcite group was linked to 3 - sulfide mineralization (beresite - low sulfidation); 4 - potassic feldspar-ankerite; 5 - oxidation cluster between kaolinite and sulfide/micas.

Qu-Kln-Ab cluster showed kaolinitization. K-Fsp and mica clusters tied together with $\mathrm{K}$ and $\mathrm{Rb}$. Barium feldspar - hyalophane associated with K-Fsp. Mica cluster combined muscovite, illite, illite-smectite and chlorite. Sulfide cluster connected with mica cluster and gold losses. Au recovery connected with As, illite, illite-smectite indirectly through the minerals formed from sulfide oxidation: jarosite, goethite and scorodite. Mica transformation to illite and illite-smectite followed oxidation of sulfides 


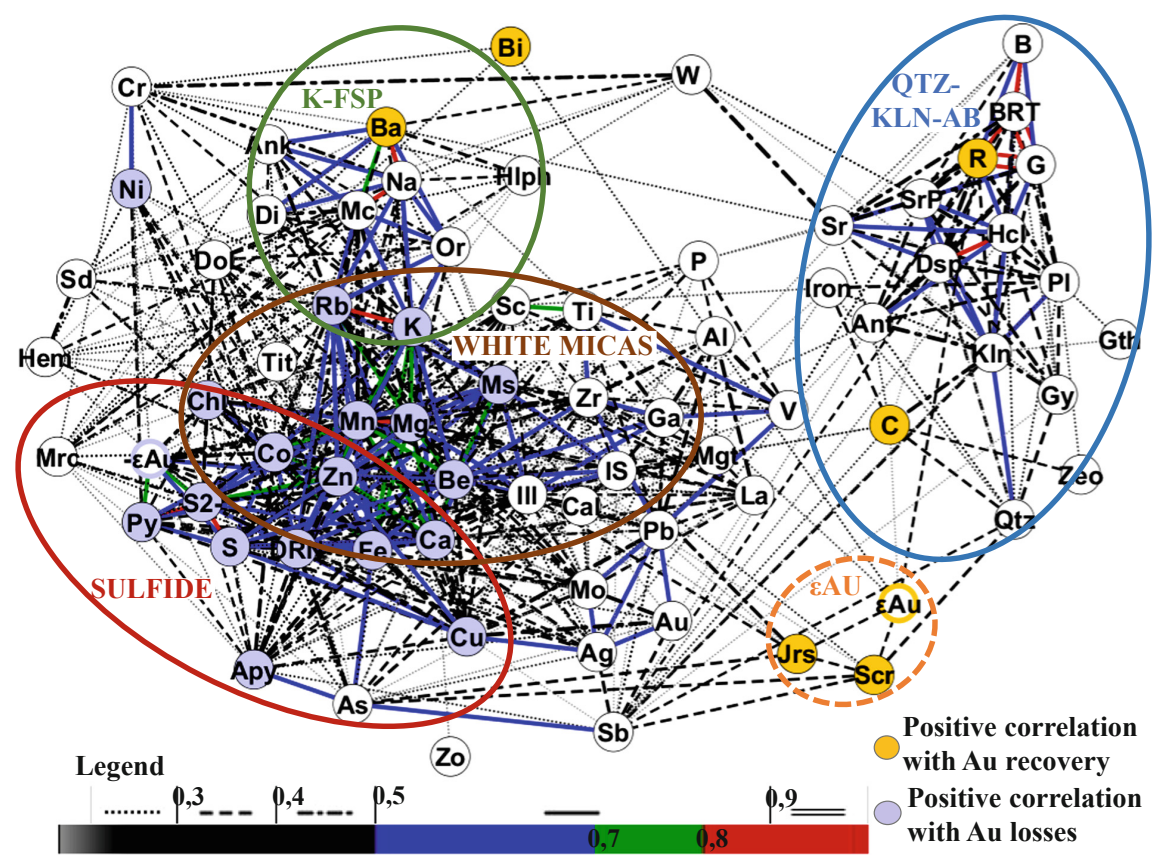

Fig. 1. Pearson correlations of 74 transformed chemical, mineral composition and cyanidation tests parameters of 51 small composite samples from Levoberezhnoye deposit

and, thus reflecting good Au leach results. Beresite group coupled with gold losses, the second ones indirectly correlated with gold recovery.

PCA analysis exposed 6 principal components, which explained $58.14 \%$ of the total variance. They described mineral composition (Fig. 2), oxidation rate, rare-metals and arsenic associations, color, grinding fineness. Results were similar to ones obtained with pair correlations: Au losses linked to sulfides, oxidation rate raised Au recovery (Fig. 2). Thus, flotation would be the best Au recovery solution from primary sulfide ore and tank cyanidation to oxide one.

Regression equation for gold recovery by cyanidation was calculated. It had relatively low $\mathrm{R}^{2}=0.46$ (1) and connected color parameter (R/BRT) and elements contents (ppm and wt\%):

$$
\begin{aligned}
& \mathbf{\varepsilon A u C N}=-96.91+\frac{185.3 \mathrm{R}}{\mathrm{BRT}}-7.83 \mathrm{Ti}(\%)-2.71 \mathrm{Co}-0.73 \mathrm{La}-1.15 \mathrm{~Pb}+0.53 \mathrm{Sc}-0.004 \mathrm{Zr}+ \\
& 1.81 \mathrm{Ga}-13.09 \mathrm{Ssfd}(\%)+10.90 \mathrm{Fe}(\%)-0.54 \mathrm{~V}+0.34 \mathrm{Ag}-1.94 \mathrm{Ni}-75.18 \mathrm{Ca}(\%)+ \\
& 0.01 \mathrm{Ba}+0.01 P
\end{aligned}
$$




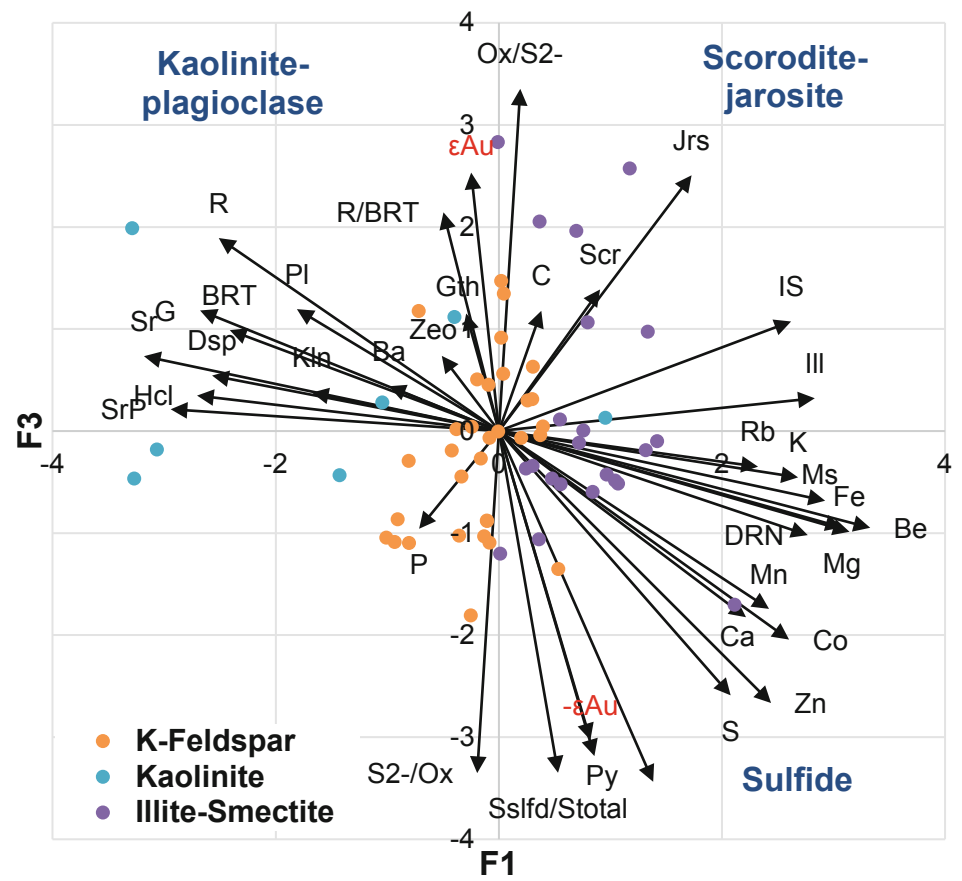

Fig. 2. Factor loadings and factor scores for factors 1 and 3 with interpretation

\section{Conclusions}

Mineral composition of the samples varied significantly from high quartz (up to $70 \%$ ) and feldspar (up to 64\%) to kaolinite (up to 45\%) and illite-smectite (up to 40\%). Au losses with cyanidation tails were bound to sulfides content. Sulfide oxidation to jarosite and scorodite and red component of sample color reflected increase in $\mathrm{Au}$ recovery. Absence of chlorite and transformation of muscovite to illite-illite-smectite also manifested Au cyanadation recovery improvement.

Revealed links between samples characteristics and regression equation, geometallurgical mapping and ore sorting can be performed based on sample color and chemical composition ( $\mathrm{Ti}, \mathrm{Co}, \mathrm{La}, \mathrm{Pb}, \mathrm{Sc}, \mathrm{Zr}, \mathrm{S}, \mathrm{Fe}, \mathrm{V}, \mathrm{Ag}, \mathrm{Ni}, \mathrm{Ba}$ ). 
Open Access This chapter is licensed under the terms of the Creative Commons Attribution 4.0 International License (http://creativecommons.org/licenses/by/4.0/), which permits use, sharing, adaptation, distribution and reproduction in any medium or format, as long as you give appropriate credit to the original author(s) and the source, provide a link to the Creative Commons license and indicate if changes were made.

The images or other third party material in this chapter are included in the chapter's Creative Commons license, unless indicated otherwise in a credit line to the material. If material is not included in the chapter's Creative Commons license and your intended use is not permitted by statutory regulation or exceeds the permitted use, you will need to obtain permission directly from the copyright holder.

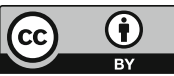

